\title{
Susu Kuda Sumbawa Meningkatkan Respon Imun Seluler Makrofag Peritoneal Mencit terhadap Salmonella typhimurium
}

\section{Sumbawa Mares Milk Increase Cellular Immune Respons of Peritoneal Macrophages of Mice Treated with Salmonella typhimurium}

\author{
Sofiyatin Reni ${ }^{1}$, Sumarno ${ }^{2}$, Edi Widjajanto ${ }^{3}$ \\ ${ }^{1} J u r u s a n$ Gizi Politeknik Kesehatan Mataram \\ ${ }^{2}$ Laboratorium Mikrobiologi Fakultas Kedokteran Universitas Brawijaya Malang \\ ${ }^{3}$ Laboratorium Patologi Klinik Fakultas Kedokteran Universitas Brawijaya Malang
}

\begin{abstract}
ABSTRAK
Susu mempunyai kandungan yang berperan sebagai imunomodulator respon imun seluler dan humoral yang melindungi tubuh dari infeksi bakteri pathogen intrasel Salmonella Thyphimurium melalui peningkatan aktifitas fagositosi dan mekanisme mikrobiosida makrofag. Studi dilakukan untuk membuktikan efek susu kuda Sumbawa terhadap peningkatan respon imun seluler yang di amati dari indeks aktifitas fagositosi, sekresi Reactive Oxygen Intermediates (ROI) dan aktivitas mikrobiosida dari sel makrofag tikus yang diinduksi dengan S. Thyphimurium dengan desain posttest-only control group. Studi dilakukan menggunakan 24 tikus usia 8-12 minggu yang di bagi dalam 1 kelompok kontrol dan 3 perlakuan pemberian susu kuda Sumbawa dengan 3 dosis $0.5 \mathrm{~m}$;/day; $1 \mathrm{ml} /$ hari selama 14 hari. Sel makrofag peritoneal diisolasi dan di beri perlakuan dengan S. Thyphimurium. Terdapat perbedaan respon imun selular antar kelompok pada semua indikator. Indeks aktifitas fagositosis makrofag paling tinggi ( $51.23 \pm 9.72$ ) dan sekresi ROI paling tinggi (67.00 $\pm 9.16 \%$ ) didapatkan pada dosis $1.5 \mathrm{ml} /$ hari. Pada dosis $0.5 \mathrm{ml} /$ hari $(77.67 \pm 15.83)$ pemberian susu kuda Sumbawa dapat menghambat pertumbuhan bakteri. Dapat di simpulkan pemberian susu kuda Sumbawa dapat meningkatkan imun seluler terhadap infeksi S. Thyphimurium.
\end{abstract}

Kata Kunci : Aktifitas fagositosis, aktifitas mikrobiosida, makrofag, Salmonella thyphimurium, sekresi reactive oxygen intermediates, susu kuda sumbawa

\begin{abstract}
The component of milk has function as immunomodulator in humoral and cellular of immune response to protect the body from infection of pathogenic intracellular bacteria like salmonella Thyphimurium by increasing the activity of Phagocytosis and the mechanism of macrophage microbiosidal. This study aimed was to reveal the effect of Sumbawa Mares Milk in increasing the celluler immune response expressed as phagocytosis activity index, secretion of Reactive Oxygen Intermediates (ROI) and the microbiosidal activity of Balb/c mice peritoneal macrophages treated with S. Thyphimurium. A post test-only control group design was performed using 24 of 8-12 weeks of age Balb/c mice divided into one control group and three treatments groups with Mares Milk intake for 14 days on different dosages such as $0.5 \mathrm{ml} /$ day; $1 \mathrm{ml} /$ day; $1.5 \mathrm{ml} /$ day respectively. The peritoneal macrophages had been isolated and treated with $S$. Thyphimurium by in vitro experiment. Our result showed that there were a significant different on phagocytosis activity index $(p=0.000)$, secretion of Reactive Oxygen Intermediates $(p=0.000)$ and activity of microbiosidal macrophages $(p=0.007)$ among groups. The highest index of phagocytosis activity of macrophage was reached the on dosage $1.5 \mathrm{ml} /$ day $(51.23 \pm 9.72)$ and the highest presentation of macrophage secreted of ROI was reached on dosage $1.5 \mathrm{ml} /$ day $(67.00 \pm 9.61 \%)$. We found that on dosage $0.5 \mathrm{ml} /$ day ( $77.67 \pm 15.83 \mathrm{cfu} /$ plate) mares milk could inhibit the growth of bacteria. In conclusions, Sumbawa Mares milk has potential ability to increase cellilar immune response to $S$. Thyphimurium.
\end{abstract}

Keywords : Mares milk, microbiosidal macrophages, phagocytosis activity, Salmonella thyphimurium, secretion of reactive oxygen intermediates

Jurnal Kedokteran Brawijaya, Vol. XXVI, No. 1,April 2010; Korespondensi: Sofiyatin Reni. Jurusan Gizi Politeknik Kesehatan Mataram, Jl. Kesehatan V No. 10 Mataram Tel. (0370) 622382 


\section{PENDAHULUAN}

Susu yang dikonsumsi masyarakat atau produk susu yang dipasarkan biasanya berasal dari susu sapi. Namun akhirakhir ini dimasyarakat banyak beredar susu kuda yang dari pulau Sumbawa yang dipromosikan sebagai obat yang dapat menyembuhkan berbagai macam penyakit (1-4). Hasil penelitian in vivo, menunjukkan susu kuda yang mengalami autofermentasi dapat meningkatkan imunitas terhadap vaksin hepatitis A pada mencit Balb/c (5). Protein susu kuda pasteurisasi dan fermentasi berperan sebagai imunomodulator pada respon imun humoral dan menstimulasi aktivitas fagositosis pada mencit Balb/c. Studi in vitro menunjukkan susu kuda Sumbawa mampu menghambat pertumbuhan bakteri patogen seperti Salmonella typhi, Staphylococcus aures, Escherichia coli, Shigella boydii $(2,3,6)$ Vibrio cholera, Pseudomonas auruginosa, Salmonella Typymurium $(2,3)$ Mycobacterium tuberculosis baik isolat standar maupun isolat klinis $(7,8)$.

Peningkatan daya tahan tubuh dapat dilakukan dengan pengaturan respon imun (imunomodulasi) (9). Salah satunya dengan peningkatan kemampuan fagositosis selsel fagosit terhadap benda asing yang masuk ke dalam tubuh (10). Salah satu sel fagosit adalah makrofag yang merupakan komponen seluler yang akan mengelimenasi patogen pada tahap imunitas inet dan memperantarai terjadinya sel imun adaptif melalui peranannya sebagai APC (antigen presenting cell) (9-11).

Bakteri S. Typhimurium yang merupakan bakteri yang bersifat intraseluler yang dapat bertahan hidup didalam makrofag dan menghindari mikrobiosidal makrofag. Merupakan bakteri yang menyebabkan salmonellosis pada mencit yang analog dengan deman typhoid yang disebabkan oleh S.Typhi pada manusia yang masih banyak menimbulkan gangguan instestinal (12).

Untuk membunuh bakteri intraseluler salah satu caranya dengan meningkatkan aktivasi makrofag, stimulasi sel T dan sitokin-sitokin yang dilepas oleh makrofag yang berkaitan dengan proses fagositosis dan membunuh mikroba. Makrofag apabila teraktivasi akan berusaha membunuh agen penginfeksi dengan cara meningkatkan aktivitas fagositosisnya dan mengembangkan mekanisme mikrobiosidal melalui sistem oksidatif maupun non oksidatif. Pada sistem oksidatif makrofag menghasilkan Reactive Oxygen Intermediates (ROI), sedangkan pada sistem non oksidatif makrofag antara lain akan meningkatkan jumlah produksi enzim-enzim lisosomal $(9,11)$.

Penelitian ini dilakukan untuk membuktikan bahwa susu kuda Sumbawa mampu meningkatkan respon imun seluler makrofag Mencit Balb/c yang dipapar bakteri $S$. typhimurium melalui peningkatan aktivitas fagositosis, sekresi ROI dan aktivitas mikrobiosidal makrofag.

\section{METODE}

Penelitian ini menggunakan hewan coba mencit spesies mus musculus galur B albino clone (Balb/c) jantan usia 812 minggu dengan berat badan rata-rata 28 gram sebanyak 24 ekor. Susu kuda Sumbawa yang digunakan berasal dari Kabupaten Bima, Nusa Tenggara Barat. Mencit dibagi dalam 4 kelompok yaitu kelompok kontrol yang diberi aquades, kelompok perlakuan dengan pemberian susu kuda Sumbawa dosis $0.5 \mathrm{ml} / \mathrm{hr}, 1 \mathrm{ml} / \mathrm{hr}$ dan $1.5 \mathrm{ml} / \mathrm{hr}$ yang diberikan selama 14 hari secara oral, kemudian diambil cairan peritoniumnya dan dilakukan isolasi makrofag peritonium dan dipapar dengan bakteri Salmonella typhimurium secara in vitro. Salmonella typhimurium yang digunakan adalah koleksi dari
Laboratorium Mikrobiologi Fakultas Kedokteran Universitas Brawijaya.

Isolasi makrofag peritonium mencit dilakukan prosedur sebagai berikut (13). Mencit dimatikan dengan klorofom, kemudian bagian abdomen disemprot dengan alkohol 70 $\%$. Bagian abdomen dibedah bagian kulit luar, dan disterilisasi dengan alkohol $70 \%$, kemudian sejumlah 10 $\mathrm{ml}$ medium RPMI dingin diinjeksikan dengan menggunakan jarum 19G kelapisan peritoneum. Abdomen ditepuk-tepuk selama 10 detik lalu diambil cairan peritoneum dengan menggunakan jarum 25G, Konsentrasi makrofag yang digunakan sekitar $10^{6} \mathrm{sel} / \mathrm{ml}$ dimasukkan dalam tiap mikroplate 24 well yang berisi cover slip, kemudian ditambahkan medium komplek $200 \mu \mathrm{l}$ dan diinkubasi pada inkubator $\mathrm{CO}_{2} 5 \%$ selama 2 jam pada suhu $37^{\circ} \mathrm{C}$, sel yang tidak melekat dibuang, sedangkan sel yang melekat dicuci dengan medium RPMI sebanyak $1 x$. Setelah dicuci, ditambahkan medium komplet kedalam tiap microplate 24 well sebanyak $500 \mu$ l dan diinkubasi kembali pada inkubator $\mathrm{CO}_{2} 5 \%$ selama 24 jam pada suhu $37{ }^{\circ} \mathrm{C}$. Setelah 24 jam kultur makrofag siap digunakan untuk uji aktivitas fagositosis makrofag, aktivitas mikrobiosidal makrofag dan kemampuan makrofag mengsekresi ROIs terhadap S. typhimurium.

Prosedur uji aktivitas fagositosis makrofag yaitu makrofag yang dikultur sehari sebelumnya dipapar bakteri $S$. typhimurium $10^{7} \mathrm{sel} / \mathrm{ml}$ dan diinkubasi pada suhu $37^{\circ} \mathrm{C}$ di shaker water bath dengan waktu inkubasi 60 menit (14). Pelet dicuci dengan PBS $1 x$, untuk menghilangkan bakteri yang tidak difagosit, kemudian dikeringkan pada suhu ruang dan difikasasi dengan metanol absolut 30 detik. Setelah kering, coverslip dipulas dengan giemsa $20 \%$ selama 30 menit lalu dicuci dengan aquades, diangkat dari sumuran kultur dan dikeringkan pada suhu kamar, setelah kering dimounting pada object glass dan diamati dibawa mikroskop cahaya pembesaran $1000 \mathrm{x}$ uji fagositosis makrofag secara kuantitatif dihitung dalam 200 sel makrofag jumlah rata-rata bakteri yang terfagosit per sel makrofag dibagi jumlah makrofag aktif.

Aktivitas sekresi ROls oleh makrofag di uji dengan metode Nitroblue tetrazolium (NBT) reduction assay (15). Pada uji ini PMA (phorbol 12-Myristate 13-Acetate) akan menstimulasi makrofag untuk mensekresi ROls. Adanya ROIs NBT akan tereduksi menyebabkan terbentuknya presipitat formazan yang tidak terlarut dan dapat dilihat dengan mikroskop cahaya. Prosedur NBT reduction assay dilakukan dengan cara makrofag dalam mikroplate 24 well dengan konsentrasi $10^{6} \mathrm{sel} / \mathrm{ml}$ dipapar dengan bakteri S. typhimurium $10^{7} \mathrm{sel} / \mathrm{ml}$ untuk tiap perlakuan, dan diinkubasi 60 menit (18). Pelet diambil dan dicuci menggunakan PBS sebanyak $1 \mathrm{x}$, pelet kemudian ditambahkan $500 \mu \mathrm{l}$ larutan NBT ( $1 \mathrm{mg} / \mathrm{ml})$ yang mengandung $1250 \mathrm{ng} / \mathrm{ml}$ PMA untuk tiap sumuran dan diinkubasi pada inkubator $\mathrm{CO} 25 \%, 37$ 으 selama 30 menit. Pelet dicuci dengan PBS 3x. Setelah kering dicat dengan $2 \%$ neutral red solution selama 15 menit, kemudian dicuci dengan aquades. Cover slip yang sudah kering pada suhu kamar diangkat dari microplate 24 well, untuk dilihat dibawah mikroskop cahaya dengan pembesaran 1000x. Gambaran makrofag yang mengsekresi ROls adalah persentase makrofag yang membentuk formazan dari 200 sel makrofag yang terlihat dibawah mikroskop cahaya.

Uji aktivitas mikrobiosidal makrofag prinsipnya melihat kemampuan makrofag untuk membunuh dan menghancurkan mikroba yang diukur dengan teknik biakan langsung pada medium bismuth sulfite agar (BSA) dan dihitung menggunakan colony counter. Uji aktivitas mikrobiosidal makrofag (16) dilakukan dengan prosedur berikut, makrofag dikultur sehari sebelumnya dalam kultur 24 well dengan konsentrasi $10^{6} \mathrm{sel} / \mathrm{ml}$ kemudian 
pada inkubator 37으 di shaker water bath dengan waktu inkubasi 60 menit Pelet ditambahkan 0,25 ml 0.5\% Triton X-100 dalam PBS tiap well untuk melisiskan makrofag, kemudian pipet berulang kali selama 8-15 menit dan diencerkan $10^{3}$ ditanam ke medium padat BSA diinkubasi 37으 c selama 18-24 jam kemudian dihitung jumlah koloni yang tumbuh.

\section{HASIL}

Pengaruh Susu Kuda Sumbawa pada Aktivitas Fagositosis Makrofag

Gambar 1 menunjukkan bakteri S.typhimurium yang difagositosis oleh makrofag. Bakteri yang paling banyak difagositosis tampak pada perlakuan susu kuda Sumbawa dosis $1.5 \mathrm{ml} / \mathrm{hr}$ diikuti dengan perlakuan susu kuda Sumbawa dosis $0.5 \mathrm{ml} / \mathrm{hr}$ dan pada kelompok kontrol terlihat paling sedikit diikuti oleh kelompok susu kuda Sumbawa dosis $1 \mathrm{ml} / \mathrm{hr}$.
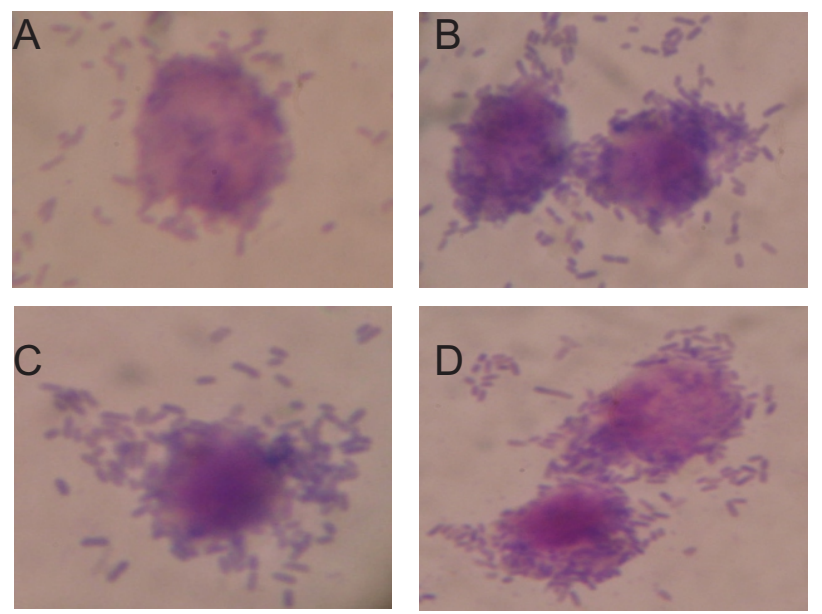

Gambar 1. Gambar makrofag peritoneum mencit Balb/c yang mengfagositosis bakteri S.typhimurium pada tiap kelompok perlakuan.

Keterangan: $A=$ Kontrol aquades, $B=$ susu kuda Sumbawa dosis 0.5 $\mathrm{ml} / \mathrm{hr}, \mathrm{C}=$ susu kuda Sumbawa Dosis $1 \mathrm{ml} / \mathrm{hr}$ dan $\mathrm{D}=$ susu kuda Sumbawa dosis $1.5 \mathrm{ml} / \mathrm{hr}$. pengecatan Giemsa, pembesaran 1000x

Aktivitas fagositosis makrofag terhadap bakteri S.typhimurium ditentukan dengan menghitung rata-rata jumlah bakteri yang terfagosit per sel makrofag dari 200 sel makrofag dinyatakan dengan indeks fagositosis. Menunjukkan indeks fagositosis makrofag yang paling tinggi pada kelompok perlakuan susu kuda Sumbawa dosis $1.5 \mathrm{ml} / \mathrm{hr} \quad(51.23 \pm 9.72)$ kemudian kelompok susu kuda Sumbawa dosis $0.5 \mathrm{ml} / \mathrm{hr}(33.00 \pm 7.64)$ dan kelompok susu kuda Sumbawa dosis $1 \mathrm{ml} / \mathrm{hr}$ $(28.13 \pm 8.67)$ yang terendah terdapat pada kelompok kontrol ( $21.53 \pm 9.86$ ). Pada perlakuan susu kuda sumbawa dosis $1 \mathrm{ml} / \mathrm{hr}$ memberikan indeks fagositosis lebih rendah dibandingkan dosis $0.5 \mathrm{ml} / \mathrm{hr}$ tetapi lebih tinggi dibandingkan kelompok kontrol. Hasil analisis dengan One-way ANOVA menunjukkan perbedaan signifikan indeks fagositosis makrofag antara kelompok perlakuan $(p<0.001)$. Hasil uji Tukey HSD menunjukkan bahwa perlakuan susu kuda Sumbawa dosis $1.5 \mathrm{ml} / \mathrm{hr}$ lebih tinggi secara signifikan dibandingkan dengan kelompok kontrol, susu kuda dosis $0,5 \mathrm{ml} / \mathrm{hr}$ dan dosis
$1 \mathrm{ml} / \mathrm{hr}$. Pemberian susu kuda Sumbawa dosis $1.5 \mathrm{ml} / \mathrm{hr}$ terbukti mampu meningkatkan indeks fagositosis makrofag mencit Balb/c yang dipapar bakteri S.typhimurium.

\section{Pengaruh Susu Kuda Sumbawa pada Kemampuan Makrofag Mengsekresi ROI}

Kemampuan makrofag dalam mengsekresikan ROls dinyatakan sebagai persentase jumlah makrofag yang memproduksi ROls pada setiap 200 sel makrofag. Kemampuan tersebut diukur dengan metode nitroblue tetrazolium (NBT) reduction assay. Superoksida akan mereduksi NBT menjadi produk reaksi formazan yang tidak terlarut.

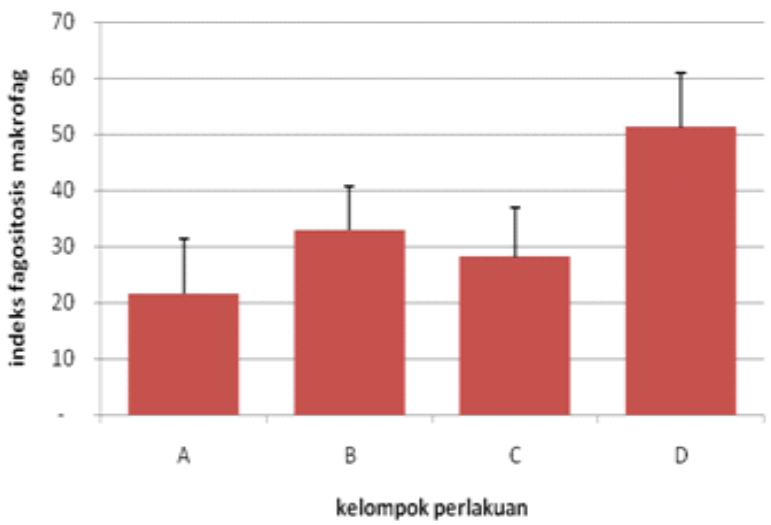

Gambar 2. Grafik rata-rata jumlah bakteri S.Typhimurium yang terfagosit yang dinyatakan dalam indeks fagositosis makrofag untuk tiap kelompok perlakuan:

Keterangan: $A=$ Kontrol Aquades, $B=$ susu kuda Sumbawa dosis 0.5 $\mathrm{ml} / \mathrm{hr}, \mathrm{C}=$ susu kuda Sumbawa dosis $1 \mathrm{ml} / \mathrm{hr}$ dan $\mathrm{D}=$ susu kuda Sumbawa dosis $1.5 \mathrm{ml} / \mathrm{hr}$.
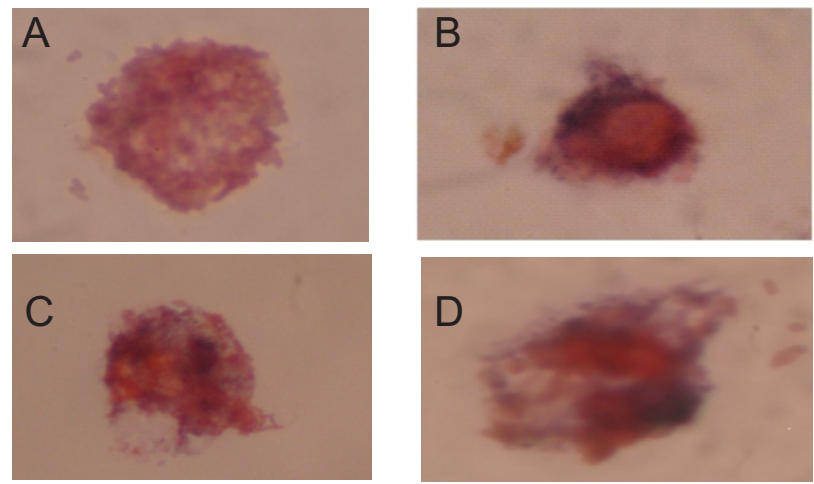

Gambar 3. Makrofag peritoneum mencit Balb/c yang mengsekresikan ROls pada tiap kelompok perlakuan.

Keterangan: $A=$ kontrol aquades, $B=$ susu kuda sumbawa dosis $0.5 \mathrm{ml} / \mathrm{hr}$, $\mathrm{C}=$ susu kuda sumbawa Dosis $1 \mathrm{~m} / \mathrm{hrl}$ dan $\mathrm{D}=$ susu kuda sumbawa dosis $1.5 \mathrm{ml} / \mathrm{hr}$. Pengecatan neutral red, pembesaran $1000 \mathrm{x}$

Pada Gambar 3 sekresi ROI yang digambarkan dengan pembentukan formazan biru yang menunjukkan adanya lonjatan respirasi. Sekresi ROI paling tinggi didapatkan pada perlakuan susu kuda Sumbawa dosis $1.5 \mathrm{ml} / \mathrm{hr}$ dan yang paling rendah pada perlakuan kontrol. 


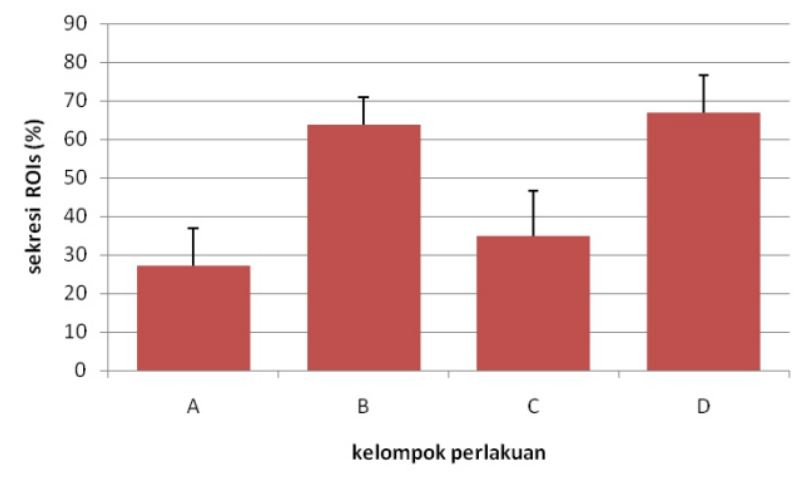

Gambar 4. Grafik Porsentase makrofag yang mengsekresikan ROIs untuk tiap kelompok perlakuan.

Keterangan: $A=$ kontrol aquades, $B=$ susu kuda sumbawa dosis 0.5 $\mathrm{ml} / \mathrm{hr}, \mathrm{C}=$ susu kuda sumbawa dosis $1 \mathrm{ml} / \mathrm{hr}$ dan $\mathrm{D}=$ susu kuda sumbawa dosis $1.5 \mathrm{ml} / \mathrm{hr}$

Gambar 4 menunjukkan rata-rata persentase makrofag yang mengsekresi ROI yang paling tinggi pada kelompok perlakuan susu kuda Sumbawa $1.5 \mathrm{ml} / \mathrm{hr}(67.00 \pm 9.61 \%)$ diikuti dosis $0.5 \mathrm{ml} / \mathrm{hr}(63.83 \pm 7.30 \%)$ dan kelompok

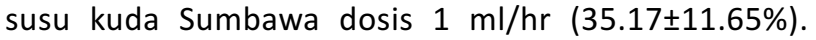
Sekresi paling rendah didapatkan pada kelompok kontrol (27. $50 \pm 9.64 \%$ ). Hasil analisis One-way ANOVA perbedaan signifikan persentase makrofag yang mengsekresikan ROIs antara kelompok perlakuan $(p<$ 0.001). Hasil uji Tukey HSD menunjukkan bahwa perlakuan susu kuda Sumbawa dosis $1.5 \mathrm{ml} / \mathrm{hr}$ dan dosis $0.5 \mathrm{ml} / \mathrm{hr}$ secara signifikan berbeda bermakna dengan kelompok perlakuan dosis $1 \mathrm{ml} / \mathrm{hr}$ dan kelompok kontrol. Hal ini membuktikan pemberian susu kuda Sumbawa dosis $0.5 \mathrm{ml} / \mathrm{hr}$ dan $1.5 \mathrm{ml} / \mathrm{hr}$ mampu meningkatkan persentase sekresi ROls yang ditunjukkan oleh sekresi positif NBT pada makrofag peritoneum mencit Balb/c yang dipapar bakteriS.typhimurium.
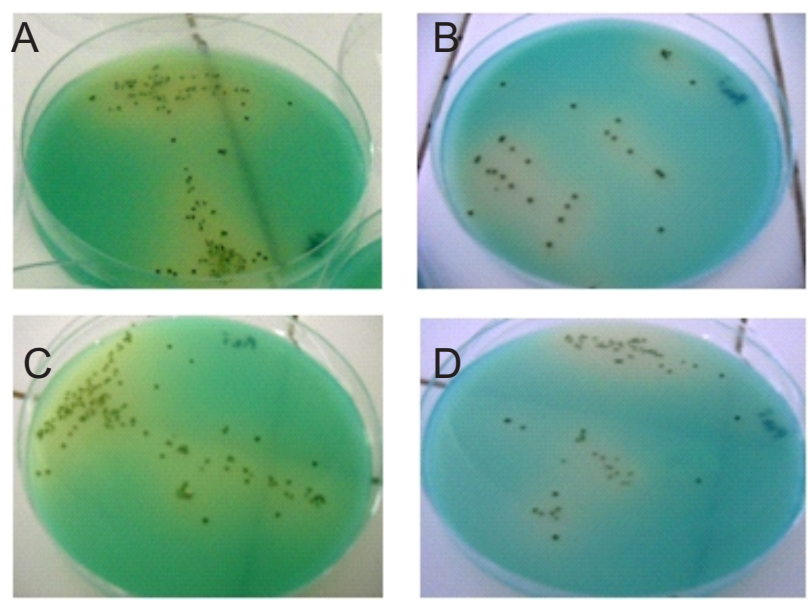

Gambar 5. Bakteri Salmonella Typhimurium setelah dilisiskan makrofag yang ditanam di medium BSA untuk tiap kelompok perlakuan

Keterangan: $A=$ kontrol aquades, $B=$ susu kuda Sumbawa dosis $0.5 \mathrm{ml} / \mathrm{hr}$, $\mathrm{C}=$ susu kuda Sumbawa dosis $1 \mathrm{ml} / \mathrm{hr}$ dan $\mathrm{D}=$ susu kuda Sumbawa dosis $1.5 \mathrm{ml} / \mathrm{hr}$. Bakteri S.Typhimurium dengan koloni berwarna hitam pekat (blackjet colony)
Pengaruh Susu Kuda Sumbawa pada Aktivitas Mikrobiosidal Makrofag

Dalam penelitian ini yang diukur adalah bakteri S.typhimurium yang ditangkap oleh makrofag dan masih hidup setelah dikultur dalam medium agar padat dan dihitung menggunakan colony counter. Bakteri S.typhimurium yang tumbuh dalam medium BSA membentuk koloni yang berwarna hitam pekat (blackjet)

Gambar 5 menunjukkan perlakuan susu kuda Sumbawa dosis $0.5 \mathrm{ml} / \mathrm{hr}$ yang paling sedikit bakteri S.typhimurium yang tumbuh. Diikuti dosis $1.5 \mathrm{ml} / \mathrm{hr}$ dan dosis $1 \mathrm{ml} / \mathrm{hr}$. sedangkan kelompok kontrol aquades terlihat yang paling banyak jumlah bakteri S.typhimurium yang tumbuh pada medium BSA. Adapun rata-rata dan standar deviasi bakteri yang masih mampu tumbuh pada mendium agar padat BSA dapat dilihat pada Gambar 6 dibawah ini.

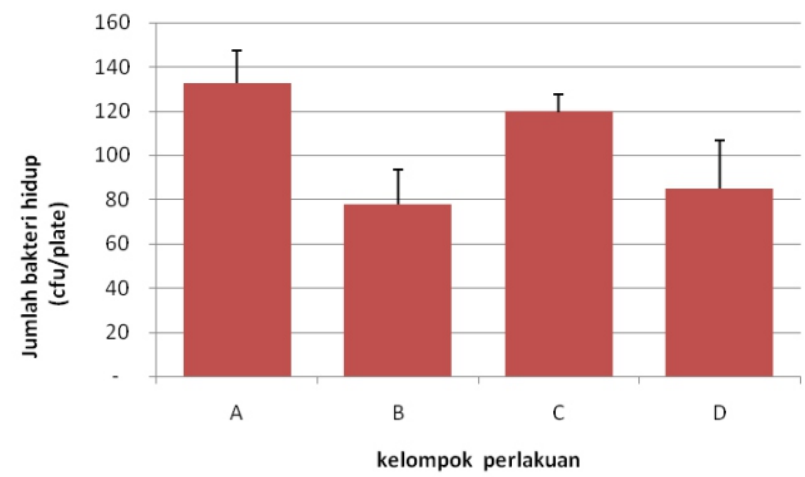

Gambar 6. Grafik rata-rata jumlah bakteri S.typhimurium intraseluler yang masih mampu tumbuh pada medium BSA untuk tiap kelompok perlakuan.

Keterangan : $A=$ kontrol aquades ; $B=$ susu kuda sumbawa dosis 0.5 $\mathrm{ml} / \mathrm{hr} ; \mathrm{C}=$ susu kuda sumbawa dosis $1 \mathrm{ml} / \mathrm{hr}$ dan $\mathrm{D}=$ susu kuda sumbawa dosis $1.5 \mathrm{ml} / \mathrm{hr}$.

Secara kuantitatif rata-rata bakteri yang masih mampu hidup secara intraseluler paling sedikit didapatkan pada kelompok perlakuan susu kuda Sumbawa dosis $0.5 \mathrm{ml} / \mathrm{hr}$ (77.67 $\pm 15.83 \mathrm{cfu} /$ plate) diikuti dosis $1.5 \mathrm{ml} / \mathrm{hr}$ (85.00 $\pm 21.65 \mathrm{cfu} / \mathrm{plate})$ dan dosis $1 \mathrm{ml} / \mathrm{hr}(119.67 \pm 8.14$ cfu/plate). Pada kelompok kontrol

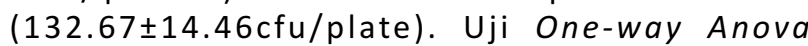
menunjukkan perbedaan signifikan aktivitas mikrobiosidal makrofag antara kelompok perlakuan ( $p$ 0.007). Hasil uji Tukey HSD menunjukkan bahwa perlakuan susu kuda Sumbawa dosis $0.5 \mathrm{ml} / \mathrm{hr}$ dan susu kuda Sumbawa dosis $1.5 \mathrm{ml} / \mathrm{hr}$ secara signifikan berbeda bermakna dengan kontrol. Sehingga dalam penelitian ini pemberian susu kuda Sumbawa dengan dosis $0.5 \mathrm{ml} / \mathrm{hr}$, dosis $1.5 \mathrm{ml} / \mathrm{hr}$ mampu meningkatkan aktivitas mikrobiosidal makrofag yang ditunjukkan oleh penurunan koloni pertumbuhan bakteri S.typhimurium pada medium BSA.

\section{DISKUSI}

Pengaruh Susu Kuda Sumbawa pada Aktivitas Fagositosis Makrofag

Hasil penelitian ini menunjukkan perlakuan susu kuda 
dengan meningkatnya kemampuan fagositosis makrofag dibandingkan pada kontrol aquades. Kemampuan fagositosis makrofag yang dinyatakan dalam indeks fagositosis paling tinggi pada dosis $1.5 \mathrm{ml} / \mathrm{hr}$. Secara normal makrofag dalam keadaan nonaktif, dan dapat diaktifkan oleh berbagai stimulan dari luar tubuh. Pada mencit yang telah mendapat susu kuda Sumbawa secara in vivo dan secara invitro makrofag peritoneum diinfeksi bakteri S.typhimurium menunjukkan peningkatan ratarata jumlah bakteri S.typhimurium yang terfagosit. Hal ini menunjukkan bahwa komponen dalam susu kuda Sumbawa mampu meningkatkan kapasitas reseptor yang dimiliki oleh makrofag dan juga meningkatkan produksi sitokin-sitokin yang mengaktivasi makrofag. Menurut Perdigon et al pemberian susu fermentasi yang mengandung salah satu bakteri Lactobacillus acidophilus, Lactobasillus casei rharmonus atau keduanya secara in vitro dan in vivo dapat meningkatkan aktivitas fagositosis makrofag peritoneum mencit (17). Peningkatan indeks fagositosis makrofag dalam penelitian ini dipengaruhi oleh kandungan bakteri asam laktat yang terkandung dalam susu kuda Sumbawa yang menginduksi produksi sitokin dan berperan dalam aktivasi makrofag. Hal ini didukung oleh beberapa penelitian yang menunjukkan bakteri asam laktat (BAL) yang berperan sebagai probiotik memiliki kemampuan sebagai aktivator yang kuat untuk sistem imun alami karena mempunyai molekul yang spesifik pada dinding selnya. Dinding sel BAL tersusun atas peptidoglycan (30-70 \% dari total dinding sel), polysaccharide dan lipoteichoic acid. Spesifik reseptor pada pepridoglycan mempengaruhi limfosit atau makrofag yang dikenali oleh reseptor makrofag toll like receptor (TLR). Toll like receptor menjembatani sistem imunitas alami ke sistem adaptif dengan menginduksi berbagai molekul efektor dan ko-stimulator. Dalam perannya tersebut, TLR mampu menginduksi respons imun baik ke arah Th1 maupun T.regulasi. Sinyal dari TLR dapat mengaktifkan respon imun non spesifik, dengan cara merangsang produksi berbagai protein penting yang terdapat pada makrofag. Toll Like Receptor (TLR) terutama mengenali sejumlah besar patogen yang berhubungan dengan PAMPs (Pathogen Associated Molecular Patterns) $(9,11)$. Salah satu PAMPs yang ditemukan pada bakteri gram positif misalnya lipoteichoic acid (LTA). Molekul biologis LTA pada BAL akan dikenali PRRs (Pattern Recognition Receptor) yaitu TLR2 dan TLR4, yang mempunyai peran penting dalam polarisasi respons imun oleh paparan mikroba.

Hasil beberapa penelitian menunjukkan bahwa komponen BAL lipoteichoic acid dapat menginduksi produksi sitokin diduga melalui dua jalur yaitu sitokin yang disekresikan terjadi apabila reseptor permukaan sel berikatan dengan antigen yang dipresentasikan ke $T$ limfosit dan melalui interaksi langsung BAL dengan sel imunokompeten $(18,19)$. Hasil penelitian menunjukkan bahwa komponen BAL lipoteichoic acid dapat menginduksi produksi sitokin Interleukin-1 (IL-1), IL-6 dan Tumor Necrosis factor-alfa (TNF- $\alpha$ ) pada sel monosit manusia (19) menginduksi produksi sitokin IL-12, IL-18 dan Interferon- $\gamma$ (IFN- $\gamma$ ) pada sel-sel mononuclear darah perifer manusia (20) dan sitokin IL-12, TNF- $\alpha$ dan IFN- $\gamma$ pada sel-sel limpa tikus (21) Hasil penelitian lain menunjukkan susu kuda Sumbawa mengandung BAL Lactobacillus sp, Weissela sp atau roksida. Selanjutnya hidrogen peroksida dapat diubah oleh myeloperoksidase menjadi asam hipoklorit sehingga lisis bakteri $(9,22)$, yang menyebabkan kemampuan makrofag dalam mengsekresikan ROI pada dosis $1 \mathrm{ml} / \mathrm{hr}$ ditemukan menurun. Hal ini diduga komponen yang dikandung oleh susu kuda mampu menghambat proses respiratory burst. Dalam komponen susu kuda Sumbawa terdapat komponen galaktoferin/laktoferin(3). Laktoferin merupakan protein pengikat metal (metal-binding protein) yang berfungsi sebagai metal-chelator (23). Kemampuan komponen susu dalam menghambat respiratory burst juga ditunjukkan oleh hasil penelitian Sabina et al, kemampuan fagositosis sel neutrofil dari sukarelawan sehat yang diberi perlakuan konsumsi susu kuda $250 \mathrm{ml} / \mathrm{hr}$ selama 3 minggu, menunjukkan penurunan proses respiratory burst namun kemampuan kemotaksis sel netrofil meningkat sehingga dalam penelitiannya diduga komponen yang ada dalam susu kuda berfungsi sebagai imunostimulator dalam proses fagositosis (24). Kemampuan makrofag dalam mengsekresikan ROls dalam perlakuan susu kuda dosis 1 $\mathrm{ml} / \mathrm{hr}$ mengalami penurunan dapat dipengaruhi oleh beberapa komponen dalam susu kuda. Pembuktian lebih lanjut perlu dilakukan dengan pengukuran spesifik enzim SOD, radikal bebas lain yang terbentuk maupun jenis sitokin yang dihasilkan sebagai pengaruh pemberian susu kuda Sumbawa.

\section{Pengaruh Susu Kuda Sumbawa pada Aktivitas Mikrobiosidal Makrofag}

Pengukuran aktivitas mikrobiosidal sel fagosit secara umum menggunakan dua pendekatan yaitu secara tidak langsung dengan mengukur komsumsi oksigen, produksi $\mathrm{H}_{2} \mathrm{O}_{2}$ atau reduksi NBT, juga secara langsung dengan melihat penurunan viabilitas mikroorganisme sebagai pengukuran aktivitas bakteriasidal (10). Sehingga pada penelitian ini juga mengukur kemampuan aktivitas mikrobiosidal makrofag secara langsung dengan melihat penurunan pertumbuhan koloni bakteri S. typhimurium.

Perlakuan susu kuda Sumbawa dosis $0.5 \mathrm{ml} / \mathrm{hr}$ dan dosis $1.5 \mathrm{ml} / \mathrm{hr}$ kemampuan mikrobiosidal makrofag meningkat. Adanya komponen susu kuda Sumbawa yang berperan sebagai imunostimulator maupun inhibitor diduga mempengaruhi hasil penelitian ini disamping cara pemberian serta dosis susu kuda yang diberikan, Hal ini didukung oleh beberapa penelitian yang menunjukkan bahwa komponen protein yang terkandung dalam susu mempengaruhi respon imun yang terjadi (24) .

Penelitian ini juga menunjukkan bahwa pemberian susu kuda Sumbawa dosis 0,5 ml/hr dan $1.5 \mathrm{ml} / \mathrm{hr}$ secara signifikan meningkatkan kemampuan mikrobiosidal makrofag namun belum mampu secara keseluruhan membunuh bakteri S.typhimurium, hal ini disebabkan karakteristik virulensi esensial yang dimiliki oleh S.typhimurium yang merupakan bakteri yang bersifat intraseluler fakultatif. Salmonella typhimurium memiliki faktor-faktor yang mampu menggagalkan proses mikrobiasidal dari sel fagosit. Faktor yang mampu menggagalkan proses mikrobiasidal dari sel fagosit. Pembuktian lebih lanjut dengan melakukan pengukuran secara spesifik ekspresi gen yang mempengaruhi aktivitas makrofag dengan pemberian susu kuda Sumbawa pada mencit yang diinfeksi bakteri S.typhimurium baik melalui metode in vitro maupun in vivo. 
Dapat disimpulkan bahwa susu kuda Sumbawa pada dosis $1,5 \mathrm{ml} /$ hari mampu meningkatkan respon imun seluler makrofag melalui peningkatan

\section{DAFTAR PUSTAKA}

1. Yuniati H. Komponen Bioaktif Protein dalam Susu Kud a Liar. (O n I i n e ) 2000 . http://digilib.litbang.depkes.go.id/go.php?id=jkpkbp pk-gdl-res-2000-heru-992-susu [diakses tanggal 17 Januari 2009].

2. Hermawati D, Sudarwanto $M$, Soekarto ST, Zakaria FR, Sudrajat S dan Tjatur RFS. Aktivitas Antimikroba Pada Susu Kuda Sumbawa. Jurnal Teknologi dan Industri Pangan. 2004; 15 (1): 47-53.

3. Hermawati. Kajian Aktivitas dan Karakterisasi Senyawa Antimikroba dari Susu Kuda Sumbawa. [Disertasi]. Institus Pertanian Bogor, Bogor. 2005.

4. Sujaya IN, Dwipayanti UNM, Suariani PNL, et al. Isolasi dan Karakterisasi Bakteri Asam Laktat dari Susu Kuda Sumbawa. Jurnal Veteriner. 2008; 9(2): 52-59.

5. Sasmito E, Rumiyati, Rahayu SW, Andriyani E, dan Istikharah R. Pengaruh Pemberian Susu Kuda Terfermentasi terhadap Imunitas Vaksin Hepatitis A pada Mencit Balb/c. Majalah Farmasi Indonesia. 2006; 17(1): 13-18.

6. Formanto B. Aktivitas Antimikroba Susu Kuda terhadap Bakteri Pathogen. [Skripsi]. Institut Pertanian Bogor, Bogor. 2001.

7. Rijatmoko D. Pengaruh Susu Kuda Sumbawa terhadap Pertumbuhan Mycobacterium Tuberculosis secara In Vitro. [Tesis]. Institut Pertanian Bogor, Bogor. 2004.

8. Pana ZK. Perbandingan Pengaruh Susu Kambing dan Susu Kuda Sumbawa terhadap Pertumbuhan Mycobacterium Tuberculosis secara In Vitro. [Tesis]. Institusi Pertanian Bogor, Bogor. 2004.

9. Roitt I, Brostoff J, and Male D. Immunology. 6th edition. London: Harcourt Publisher Ltd; 2001.

10. Abbas AK, Lichtmann AH, and Pober JS. Cellular and Molecular Immunology. 4th edition. Philadelphia: WB Saunders Co; 2000.

11. Bellanti JA. Imunologi III (Judul Asli: Immunology, Veterinary Clinical Immunology Laboratory). Volume 2 Wahab SA (Penerjemah). Yogyakarta: Gadjah Mada University Press; 1993; hal. 280-293.

12. Mittrucker HW and Kaufmann SH. Immune Response to Infection with Salmonella Typhimurium in Mice. Journal of Leukocyte Biology. 2000; 67; 457-463.

13. Lewia JG. Isolation of Alveolar Macrophages, Peritoneal Macrophages and Kuffer Cells. In: Burlesson GR, et al (Eds). Methods in Imunotoxicology Volume 2. USA: John Willey \& Sons Inc. Publ; 1995; 19 20. indeks fagositosis,sekresi ROI dan aktivitas mikrobiosidal makrofag mencit yang dipapar bakteri S.typ himurium.

14. Warren J, Mastroeni P, Dougan G, et al. Increased Susceptibility of C1q-deficient Mice to Salmonella Enteric Serovar Typhimurium Infection. Infection and Immunity. 2002; 70: 551-557.

15. Muthmainah. Studi Aktivitas Sekresi ROls Makrofag Mencit yang Distimulasi dengan Stimulant Spesifik dan Non Spesifik selama Infeksi Toxoplasma Godii. BioSMART. 2004; 6: 79-84.

16. Winarsih S. Respon Imun Seluler dan Protektivitas In Vivo Protein AdhO36 Salmonella Typhi (Upaya Memperoleh Kandidat Vaksin Deman Tifoid). [Disertasi]. Universitas Barawijaya, Malang. 2005.

17. Perdigon G, Macias MEN, Alvarez S, Oliver G, dan De Holgado RAP. Systemic Augmentation of the Immune Response in Mice by Feeding Fermented Milks with Lactobacillus Casei and Lactobacillus Acidophilus. Immunology. 1988; 63: 17-23.

18. Bhakdi S, Klonisch T, Nuber $\mathrm{P}$, and Fischer $\mathrm{W}$. Stimulation of Monokine Production by Lipoteichoic Acid. Infection and Immunity. 1991; 59 : 4614-4620.

19. Heumann D, Barras C, Severin A, Glauser MP, and Tomasz A. Gram-positive Cell Walls Stimulate Synthesis of Timor Necrosis Factor Alpha and Interleukin-6 by Human Monocytes. Infection and Immunity. 1994; 62: 2715-2721.

20. Matsuzaki $\mathrm{T}$ and Chin J. Modulation Immune Responses with Probiotik Bacteri. Immunology and Cell Biology. 2000; 78: 67-73.

21. Mettienen M, Matikainem S, Vuopio Varkila J, et al. Lactobacilli and Streptococci Induce Interleukin-12, IL18 and Gamma Interferon Production in Human Peripheral Blood Mononuclear Cell. Infection and Immunity. 1998; 66: 52-60.

22. Murray RK, Granner DK, Mayes PA, and Rodwell VW. Biokimia Harper. Jakarta: Encourage Creativity; 1998; 25: hal. 727-731

23. Nagasako $Y H$, Saito $Y$, Tamura $S$, Shimamura and Tomita M. Iron-binding Properties of Bovine Lactoferrin in Iron-rich Solution. Journal of Dairy Science. 1993 ; 76(7) : 1876-1881.

24. Ellingers $S$, Linscheid KP, Jahnecke $S$, Goerlich $R$, and Enbergs $\mathrm{H}$. The Effect of Mare's Milk Consumption on Functional Elements of Phagocytosis of Human Neutrophil Granulocytes from Healthy Volunteers. Food and Agricultural Immunology. 2002; 14(3): 191200 